\title{
Jacques Rancière e a História: uma introdução
}

\author{
Jacques Rancière and History: an introduction
}

André Fabiano Voigt*

\begin{abstract}
Resumo
O presente artigo pretende introduzir as contribuições do filósofo francês Jacques Rancière a despeito das questões relativas à historiografia francesa contemporânea. Inspirada em um modelo herdado de escrita de Jules Michelet, durante o século XIX, a Nova História - bem como a História social/cultural das últimas décadas - se estabelece no cenário atual em ruptura com as regras da retórica e poética antigas, e em convergência com o programa estético da poética romântica do século XIX, aproximando, portanto, História e Literatura em um mesmo regime de verdade: o da historicidade democrática, que considera a "fala excessiva" em um mesmo patamar que a dos oradores e dos "vencedores", isto é, em um mesmo plano de igualdade estética.
\end{abstract}

Palavras-chave: Jacques Rancière; Nova História; regime estético da arte; Jules Michelet; Fernand Braudel.

\begin{abstract}
The present article intends to introduce the theme of the contributions that the French philosopher Jacques Rancière makes to think questions of the contemporary French historiography. Inspired by a model inherited from the writing of Jules Michelet during the nineteenth century, the Nouvelle Histoire - as well as the social/cultural History of the last decades - is established in the current scenario in rupture with the rules of old rhetoric and poetics, in convergence with the aesthetic program of nineteenth-century Romantic poetics, thus bringing history and literature closer in the same regime of truth: that of democratic historicity, which considers the "excessive speech" on the same level as that of orators and "winners", in the same plane of aesthetic equality.
\end{abstract}

Keywords: Jacques Rancière; Nouvelle Histoire; aesthetic regime; Jules Michelet; Fernand Braudel.

Que a gente, com razão, enalteça como modelos as obras dos antigos e chame seus autores de clássicos, como uma espécie de nobreza entre os escritores que pelo seu exemplo dão leis ao povo, parece indicar fontes a posteriori do gosto e refutar a autonomia do mesmo em cada sujeito. [...] Não há absolutamente nenhum uso das nossas forças, por livre que ele possa ser, e mesmo da razão [...], que não incidiria em falsas tentativas se cada sujeito sempre devesse começar totalmente da disposição bruta de sua índole, se outros não o tivessem precedido com as suas tentativas, não para fazer dos seus sucessores simples imitadores, mas para pôr outros a caminho pelo seu procedimento, a fim de procurarem em si próprios os princípios e assim tomarem o seu caminho próprio e frequentemente melhor (KANT, 2008, p. $129-130, \S 32)$.

\footnotetext{
* Doutor em História pela Universidade Federal de Santa Catarina (UFSC). Professor do Instituto de História e do Programa de Pós-Graduação em História da Universidade Federal de Uberlândia (UFU).

* Artigo relacionado ao projeto "O conceito de "cena" em Jacques Rancière como ferramenta teóricometodológica para a análise histórica da arte", financiado com recursos do Edital 01/2015 FAPEMIG.
}

Recebido em outubro de 2017 | Aprovado em março de 2018. 
Escrever sobre o trabalho de um autor que busca, no decorrer de sua obra, enfatizar o papel da autonomia do juízo de cada um - apesar da tradição, que sempre nos coloca grilhões a cada vez que procuramos apenas discordar de sua autoridade pode parecer uma repetição de um antigo critério empregado no meio acadêmico: o de buscar, em um autor estrangeiro, um argumento de autoridade para refutar os outros, devido a sua consistência e aceitação em outros meios supostamente melhor gabaritados. Contudo, é justamente outra a postura aqui tomada para tratar de um autor heterodoxo acerca da História: assumir um feliz encontro de ideias com um autor estrangeiro ou não - para que, em contrapartida, possamos seguir nosso próprio caminho e não simplesmente imitá-lo. Sapere aude.

Jacques Rancière é um filósofo que, sobretudo a partir de seu livro La nuit des prolétaires (A noite dos proletários em português), em 1981, assume um caminho que vai na intersecção entre a Filosofia, a História e a Literatura. Pretendemos, aqui neste estudo, levantar alguns aspectos principais da trajetória intelectual de Rancière que apontam para elementos importantes na análise multifacetada de seu trabalho, cuja pretensão é de pensar a História a partir de outros critérios que não aqueles colocados, veementemente, por uma tradição acadêmica consolidada nessa área de conhecimento.

Iniciaremos sua trajetória, portanto, em seus primeiros trabalhos realizados em conjunto com Louis Althusser, sua posterior ruptura e, por sua vez, o desenvolvimento de um caminho próprio para pensar sobre assuntos relevantes acerca da escrita da História.

\title{
Jacques Rancière: tempo, História e crítica da ideologia
}

\begin{abstract}
Um outro ponto é o que certas pessoas em um dado momento me influenciaram, pessoas em cuja linhagem eu posso me reconhecer. [...] Althusser, um certo desafio para a ideia de história, uma certa ideia da multiplicidade do tempo a qual, em um sentido, tenho o sentimento de ter sido mais fiel que o próprio Althusser (RANCIÈRE, 2012, p. 90).
\end{abstract}

É com essa reflexão, feita por Rancière no livro-entrevista, La méthode de l'égalité (2012), que pretendemos começar a nossa análise do referido autor no debate sobre o tema. A influência recebida de Althusser referente à noção de multiplicidade do tempo parece marcante em sua trajetória acadêmica. Entretanto, isso faria de Rancière 
um "estruturalista" aos moldes althusserianos? Vejamos como essa questão se põe em alguns de seus escritos.

Inicialmente, Rancière escreveu um capítulo no livro Ler o Capital, em que fundamenta uma análise, amplamente influenciada pelo pensamento althusseriano, da ruptura marxista, entre os Manuscritos de 1844 e $O$ Capital, no que diz respeito ao conceito de alienação. Nele, o autor desenha um rompimento entre essas duas obras, na medida em que observa, na primeira, uma influência de Feuerbach em sua leitura antropológica da alienação (os sujeitos são alienados de sua essência na produção capitalista, assim como a essência do homem, na religião, estaria alienada em Deus na esfera do pensamento). Em $O$ Capital, por sua vez, seria possível notar uma inspiração em Kant, que muda a perspectiva da alienação de uma dimensão antropológica para uma dimensão dupla, sensível e suprassensível (a alienação não é um problema centrado nos sujeitos, mas na própria estrutura dupla e contraditória da mercadoria). Essa estrutura dupla da mercadoria estaria centrada na identidade entre trabalho concreto (valor de uso) e abstrato (valor de troca), resultado de um processo social, cuja causa está nas relações sociais de produção capitalistas (RANCIÈRE, 1979, p. 75-172).

Dessa maneira, o problema da alienação e do fetichismo da mercadoria em Marx, nas obras da maturidade, está na maneira pela qual este denuncia a existência de uma relação direta entre a característica dupla do trabalho humano e sua "estrutura social determinada", isto é, em um modo de produção determinado, as práticas sociais funcionam em conjunto com os conceitos, noções e percepções operacionalizados em seu próprio modo. Portanto, essa questão não seria resolvida com um projeto de "educação emancipadora da humanidade" a respeito da alienação, mas sim, a partir da mudança da própria estrutura social de atribuição de valor dentro do modo de produção capitalista. Não se trata, portanto, de uma questão relacionada a uma dimensão linear do tempo e da história (em que os sujeitos romperão dialeticamente a dominação capitalista quando conhecerem as ideologias que os manipulam), mas sim, ao funcionamento dos diversos elementos da estrutura que estão em coexistência e fazem com que o modo de produção seja socialmente reconhecido e implementado. Dessa maneira, Rancière conclui que:

Impõe-se-nos portanto realizar aqui um movimento do qual Marx nos deu a figura exemplar e interrogar os próprios termos da questão, e sobretudo o conceito de história. Se não formos capazes de solucionar o problema, saberemos pelo menos em que terreno ele pode ser resolvido: o de um conceito diferente de história (RANCIÈRE, 1979, p. 171-172). 
Até que ponto Rancière foi fiel a tal concepção? Diríamos que o filósofo francês foi bastante fiel às conclusões que chegou em sua análise acerca da alienação e do fetichismo da mercadoria. Talvez tenha sido a partir dessas constatações que o autor tenha formulado a sua concepção de regimes de historicidade e de percepção da arte. Entretanto, a questão continua: teria sido a análise do autor uma mera aplicação da análise althusseriana? Acreditamos que não, sobretudo, no que tange aos limites colocados pela distinção entre ideologia e ciência no pensamento de Althusser.

Em entrevista realizada em 2014 e publicada na revista, Práticas da História, no ano seguinte, Rancière comenta que, após os movimentos de maio de 1968, na França, ele inicia uma análise da distância entre as "aspirações reais dos movimentos sociais" e "tudo o que foi dito na tradição marxista” (RANCIÈRE, 2015, p. 187). Em 1969, escreve um texto significativo, publicado apenas em 1973, pela revista L'homme et la société, que demonstra sua discordância em relação a Althusser. Nele, Rancière expõe os problemas da teoria da ideologia política no pensamento althusseriano. Em crítica marcante aos argumentos postos em textos como Problemas estudantis (Problèmes étudiants) - publicado, em 1964, na revista La Nouvelle Critique -, o autor aponta que o principal problema da análise althusseriana é a distinção entre ideologia e ciência no que diz respeito ao papel das universidades. Tal distinção encontra-se relacionada à própria definição da função pedagógica. Se Althusser teria afirmado que a função pedagógica tem como objeto a "transmissão de um determinado conhecimento a sujeitos que não o possuem" baseada na "desigualdade entre conhecimento e falta de conhecimento" (ALTHUSSER; MONTAG, 2011, p. 14), ${ }^{1}$ o papel da ciência em Althusser aparece com suas "cores verdadeiras": a de justificar o puro ser do conhecimento ou, mais precisamente, a de "justificar a dignidade eminente dos detentores do conhecimento" (RANCIÈRE, 2011, p. 144). Ou seja, se a ideologia mascara os interesses da classe dominante e se a ciência seria o instrumento de luta contra as ideologias. Esta última não repõe a hierarquia entre os que "sabem" e os que "não sabem", cuja superioridade dos intelectuais em relação aos demais deposita qualquer possibilidade de mudança social? Isso não recolocaria a alienação como um problema antropológico que poderia ser sanado pela "educação emancipadora", que,

\footnotetext{
${ }^{1} \mathrm{O}$ artigo de Althusser, intitulado "Problèmes étudiants" e inicialmente publicado em francês na revista La Nouvelle Critique em 1964, foi traduzido parcialmente por Dick Bateman para o idioma inglês e publicado em 1967. A presente citação encontra-se no texto traduzido por Bateman e anexo ao artigo de Warren Montag, intitulado "Introduction to Althusser"s "Student Problems" e publicado na Revista Radical Philosophy, no ano de 2011 (MONTAG, 2011).
} 
contraditoriamente, aposta na capacidade dos "superiores" em demonstrar aos “inferiores" quais são os mecanismos de dominação? Mas essa demonstração não é feita ao custo de se recolocar incessantemente essa hierarquia? Parece-nos que esse é o principal ponto da crítica rancieriana em relação a Althusser: o de querer depurar a teoria marxista da história de toda e qualquer noção ideológica do tempo histórico, ao custo de repor na capacidade da ciência - e, por sua vez, dos intelectuais - a saída dos problemas advindos do modo de produção capitalista.

Embora Rancière tenha elaborado o livro La leçon d'Althusser, em 1974, com base em uma crítica detalhada às teses althusserianas do ponto de vista do maoísmo (RANCIÈRE, 2011), entendemos que sua crítica às noções de tempo e história presentes nas práticas dos historiadores acadêmicos segue por outros meios em seus trabalhos posteriores.

Em sua investigação, após 1968, sobre a "distância que havia entre a teorização marxista do que seria um movimento operário, popular, revolucionário e a realidade dos movimentos subversivos", Rancière faz um trabalho de investigação histórica em que analisou, nos arquivos franceses, "as formas de pensamento e ação operários" no momento em que "Marx havia começado a falar sobre a revolução" (RANCIÈRE, 2015, p. 187). Apesar de ter partido de um ponto de vista identitário, buscando uma identidade operária como forma de pensar os movimentos da época, acabou por encontrar nos arquivos coisas completamente diferentes:

\footnotetext{
Não eram os operários que promoviam uma cultura operária, popular, ou uma linguagem especificamente operária, pelo contrário, eram essencialmente os operários que buscavam sair de uma certa identidade operária. Lá onde eu procurava um processo de formação de uma identidade, encontrei, ao contrário, processos de desidentificação, isto é, as pessoas não falavam uma língua própria dos operários, mas ao contrário, procuravam emprestar a linguagem dos outros, seja para fazer a argumentação, por exemplo, de uma greve, seja para incorporar as palavras, as personagens, as situações da poesia romântica ou os grandes romances da época romântica (RANCIÈRE, 2015, p. 188).
}

Dessa maneira, ele se viu em uma ruptura com as práticas dos historiadores por entender que, conforme estes, as "palavras não são mais que palavras" e "o que conta são os fatos" (RANCIÈRE, 2015, p. 188). O filósofo francês começou a analisar "o tecido de palavras através das quais os operários se apropriaram" (RANCIÈRE, 2015, p. 188) para, a partir daí, pensar como se deu a subversão das identidades operárias, o que, obviamente, contraria a "dramaturgia das identidades", caras a uma 
visão de tempo e de história que pensa a partir de regularidades tomadas a priori. Assim, Rancière escreve sua tese, A noite dos proletários, publicada em 1981, a partir de uma prática de pesquisa histórica diferente daquela usada pelos historiadores acadêmicos, justamente, por pensar uma relação de descontinuidade entre as palavras $e$ os fatos na construção de uma narrativa histórica:

\begin{abstract}
Havia a tradição herdada do marxismo, onde havia a história operária, por exemplo, que era feita por estratos - o econômico, depois o social, depois o político, depois o sociológico, ao alto... - e eu, ao contrário, fazia uma história onde não havia absolutamente diferença entre os níveis. Fazia uma história onde as palavras não eram a expressão de coisas, não estavam mais como as formas de tomada de consciência de uma situação, mas onde as palavras verdadeiramente operavam por si próprias (RANCIÈRE, 2015, p. 190).
\end{abstract}

Dessa maneira, pode-se notar o quanto Rancière distancia-se, tanto da tradição historiográfica marxista quanto do estruturalismo althusseriano. Em vez de pensar em termos de uma historicidade que submete os conceitos à lógica da sucessão dos eventos - ao mesmo tempo rejeitando analisar os conceitos e palavras por meio de uma estrutura nos moldes althusserianos -, Rancière pensa a História como um tecido que coloca as palavras, conceitos e noções em conjunto e em descontinuidade com os eventos, mantendo a noção do tempo histórico como coexistência de diversas práticas e comportamentos em um determinado momento, em contraposição à preponderância das regularidades sociais (classe, cultura, etc), que consideram a dissidência como desequilíbrio dialético (antítese) do todo estabelecido a priori. Dessa maneira, é possível analisar as formas dos movimentos revolucionários de um modo diferente da noção antropológica de "tomada de consciência", visto que a consciência não é prérequisito para a ação do mesmo modo que as ações revolucionárias dos operários não coincidem com a formação de uma "identidade operária" homogênea. ${ }^{2}$

\footnotetext{
${ }^{2}$ Ver, para maiores detalhes a respeito desse assunto, os livros A noite dos proletários (1988) e Louis Gabriel Gauny: le philosophe plébéien (1983). Na primeira obra, o autor trata, entre outros assuntos, dos movimentos operários e da imprensa operária a partir da década de 1830. Neles, em vez de notar uma identificação com uma ideia pressuposta de "classe", o autor percebeu nas fontes da imprensa operária uma forma de pensar a liberdade de um modo muito semelhante à ideia de um "estado estético do homem" - inspirado nas ideias de Schiller - em que o trabalho seria superado pela arte e pela beleza como fator de união comunitária. Entre algumas personagens importantes desse tema pesquisado pelo autor, está o marceneiro e taqueador Louis-Gabriel Gauny, chamado de "filósofo plebeu", devido a seus vários textos escritos publicados na imprensa operária do século XIX, na França. Em seus textos, Gauny questiona a identidade de classe junto aos "operários" de maneira pouco ortodoxa, ao escrever textos de literatura e filosofia, cujos padrões refinados de escrita são bastante diferentes em comparação aos vistos na "imprensa operária" da época (RANCIÈRE, 1983, 1988).
} 


\section{A História como "anti-retórica" e uma questão de "poética do saber": a inauguração de uma nova historicidade}

Seguindo esta mesma problemática sobre a História - abordando o uso de palavras, conceitos e o papel dos sujeitos nas ações históricas -, Rancière trata desta imbricada questão em seu livro Les noms de l'histoire: essai de poétique du savoir (Os nomes da história: ensaio de poética do saber em português), publicado originalmente em francês, em 1992. Nele, o autor trata da História que busca obter um caráter de ciência, sobretudo a partir da chamada "Nova História" francesa. Ao sair da antiga crônica e dos velhos métodos, a História viu-se obrigada a "distanciar-se dos sujeitos tradicionais da história e dos meios de verificação ligados à sua visibilidade", chegando ao ponto em que se confundem "o próprio sentido do que é um sujeito ou um acontecimento" (RANCIÈRE, 1994, p. 10-11). No surgimento da Nova História, Rancière aponta a existência de um "triplo contrato":

[...] um contrato científico que obriga a descobrir a ordem escondida sob a ordem aparente substituindo as correlações e os cálculos exatos de um processo complexo na escala dos níveis e das grandezas visíveis da política; um contrato narrativo que comanda a inscrição das estruturas deste espaço fechado ou as leis deste processo complexo nas formas legíveis de uma história que comporta começo e fim, personagens e acontecimentos; um contrato político que liga o invisível da ciência e o legível da narração às restrições contraditórias da idade das massas: grandes regularidades da lei comum, grandes tumultos da democracia, revoluções e contrarrevoluções [...] (RANCIÈRE, 1994, p. 16-17, grifos nossos).

Da mesma forma, esse "triplo contrato" que poderia satisfazer as lacunas deixadas pelos velhos métodos - relacionados à vida dos reis, príncipes, generais e seus embaixadores, relatando seus atos e motivações - acaba por demonstrar um problema fundamental da Nova História: o de que, ao tratar das "multidões anônimas", ela abandona os preceitos da retórica da Antiguidade greco-romana e se estabelece por meio do que o autor chama de "poética do saber", ou seja, de um

[...] estudo do conjunto dos procedimentos literários pelos quais um discurso se subtrai à literatura, se dá um estatuto de ciência e o significa. A poética do saber se interessa pelas regras segundo as quais um saber se escreve e se lê, se constitui como um gênero de discurso específico. [...] Sem dúvida, ela pertence muito particularmente a estas ciências ditas humanas e sociais que, há dois séculos, tentam com diferentes sortes ganhar seu lugar no concerto das verdadeiras ciências, de descartar a suspeita interminável de pertencer ainda às obras de literatura ou da política, até das duas ao mesmo tempo (RANCIÈRE, 1994, p. 15-16). 
Em suma, Rancière defende a ideia que a Nova História, em uma operação de “poética do saber", transforma a antiga crônica da vida e atos políticos dos nobres e militares em um discurso com aspirações científicas, ao mesmo tempo em que procura por meio de seus procedimentos - encobrir seu parentesco com um fenômeno relativamente recente na épistémè moderna: o surgimento da literatura como forma específica de escrita.

Mas, como a História, em sua versão acadêmica contemporânea, teria abandonado os critérios da retórica e da eloquência - tão defendida desde Vico (1990), passando por Gadamer (2008) e chegando até Carlo Ginzburg (2002) como a base a partir da qual se fundamenta o discurso histórico e a pesquisa histórica - e adotada, por sua vez, critérios próximos ao da literatura? Isso não seria o mesmo que atestar a "perda de significado" da História como registro dotado de autoridade sobre o passado, servindo de eixo norteador para o futuro da humanidade? Não, Rancière não entra no coro de autores que defendem o "luto" da História e de seu necessário "resgate" de autoridade perante às outras áreas do conhecimento, tampouco aponta seu suposto "deslocamento" para uma visão "neocética" ou "pós-moderna". Em contrapartida, o autor francês sustenta que a chave interpretativa para a mudança de abordagem da Nova História está atrelada a aspectos fundamentais do programa estético da poética romântica do início do século XIX, cujo modelo foi empregado por Jules Michelet, passando pela escrita do Mediterrâneo, de Fernand Braudel, e chegando à História social/cultural das últimas décadas. Vamos tratar dos três elementos principais dessa démarche, realizada por Rancière, para demonstrar a operação realizada pela Nova História.

Em primeiro lugar, a História que busca um estatuto de ciência - sobretudo a partir do século XIX - ultrapassa um critério fundamental dos postulados da retórica e poética antigas, ambas inspiradas pelos modelos greco-romanos: deixa de se basear na ordem do verossímil e na exemplaridade dada pela tradição. A verossimilhança (eikós) e a importância do exemplum (parádeigma) são elementos recorrentes na tradição greco-romana que orientaram uma série de estudos históricos desde a Antiguidade, uma vez que dão sustentação lógica aos seus argumentos a partir da adoção a priori de premissas universais dadas pela tradição, pressupondo uma ordem estabelecida também a priori como base para julgar o eventual, o fato particular.

Como exemplo dessa questão, Rancière retoma um caso interessante em seu livro: o da fala de Percennius, soldado raso que faz um discurso sobre as injustiças 
sofridas pelos soldados após a morte do imperador Augusto e em plena vacância de poder no Império Romano, relatado no primeiro livro dos Anais de Tácito.

Embora a fala de Percennius acerca das injustiças relacionadas aos soldados romanos tenha sido fundamentada em argumentos persuasivos - próximos aos de um bom orador político -, Tácito prepara o leitor para receber os argumentos do indivíduo como uma "fala fora de lugar":

Estava no acampamento um certo Percênio, que antes tinha sido chefe de uma claque teatral, agora soldado raso; possuía uma língua procaz e, graças ao seu antigo ofício, uma certa habilidade em dirigir multidões. Este começou a incitar os homens inexperientes, que se preocupavam com a situação do ofício dos soldados após a morte de Augusto, em reuniões noturnas, ou também ao entardecer, quando os mais inteligentes já tinham dispersado, e os piores se reuniam ao seu redor. Finalmente, quando já se tinha achado uma certa quantidade de outros agentes da sedição, ele ordenou uma reunião geral, como se fosse comandante-chefe, e dirigiu aos soldados as seguintes perguntas [...] (AUERBACH, 2004, p. 30). ${ }^{3}$

De acordo com Rancière, Tácito, "antes mesmo de dar a Percennius essa fala convincente, ele a declarou nula e malsucedida [...] Percennius não tinha que falar. No entanto, Tácito o faz falar. E sua fala é ordenada, precisa, convincente" (RANCIÈRE, 1994, p. 34). O historiador romano, ligado à tradição senatorial, colocou as palavras na boca de Percennius, justamente, para lhe tirar qualquer forma de credibilidade, por mais que o conteúdo de seus argumentos fosse persuasivo como de um político ou de um comandante de tropas. Como bem aponta o filósofo francês:

Refazer este discurso não é tarefa de documentação mas de invenção. Tratase de saber o que pôde dizer um personagem deste tipo em uma tal situação. [...] Estes são pedaços de retórica, compostos segundo as regras da conveniência e da verossimilhança, à imitação de modelos e para servir de modelos, nas escolas, a outros imitadores (RANCIÈRE, 1994, p. 35).

A retórica, baseada nos preceitos da inventio, dispositio e elocutio permite à primeira um espaço para a capacidade engenhosa do orador em encontrar os lugarescomuns (topoi), a partir dos quais ele assenta sua base de entendimento comum com a assembleia de ouvintes. Como expôs Cícero, no primeiro ensaio de seu livro De inventione: "A invenção consiste em encontrar os argumentos verdadeiros ou verossimilhantes, próprios a tornar nossa causa convincente" (CICÉRO, 2002, p. 6364).

\footnotetext{
${ }^{3}$ Outra versão desse texto, traduzido para o português, também pode ser lida em (TÁCITO, 1950, p. 1416, livro I, XVI-XVIII). Preferimos usar a de Auerbach por ter sido, a nosso ver, melhor adaptada a uma linguagem mais atual e que proporcionaria, portanto, melhor leitura.
} 
Poderíamos dizer que, dentro da lógica em que se insere a relação entre a narrativa histórica da Antiguidade e a verossimilhança retórica, Tácito teria anulado o discurso de Percennius para que ele servisse de exemplo de usurpador oportunista, cuja fala seria neutralizada de princípio pelos letrados do futuro, dando "lições de política aos príncipes e aos chefes de estado" (RANCIÈRE, 1994, p. 37). Entretanto, o autor afirma que Tácito teria criado também "um modelo de eloquência subversiva para os oradores e os simples soldados do futuro":

Todos os que não têm lugar para falar se apoderarão destas palavras e destas frases, destas argumentações e destas máximas, para constituir para a subversão um corpo novo de escrita. A hidrofobia regicida e a metafísica dos direitos do homem aí se alimentarão, para o desespero de Hobbes e de Burke, para criar a cena da revolução moderna, da revolução dos primórdios do Livro (RANCIÈRE, 1994, p. 38, grifos do autor).

Dessa maneira, o filósofo francês entende que a fala dotada de sentido e de autoridade prévia, própria da retórica antiga, dará espaço à "fala fora de lugar", que se inicia quando os oradores modernos empregam os exemplos do passado, retirados dos clássicos da Antiguidade, para lhes alterar o valor antes atribuído pelos autores da tradição. A fala do soldado oportunista e enganador, entre outras, servirá de inspiração para que os revolucionários - sobretudo na Revolução Francesa - a empreguem para que a autoridade não esteja distribuída conforme o cargo em que se ocupa na sociedade de "seu tempo", mas que o conteúdo de seus argumentos seja validado como um relato verdadeiro sobre o estado de coisas em um governo considerado injusto, como se fosse atual. Assim, o medo que Hobbes teria das sedições estava, justamente, no empréstimo que os indivíduos fariam dos clássicos greco-romanos, causando uma doença no corpo social semelhante à hidrofobia (raiva) nos cães:

A partir de leitura, digo, de tais livros, os homens resolveram matar seus reis, porque os autores gregos e latinos, nos seus livros e discursos de política, consideraram legítimos e louvável fazê-lo, desde que antes de matar o chamasse de tirano. Pois não dizem que seja legítimo o regicídio, isto é, o assassinato de um rei, mas sim, o tiranicídio, isto é, o assassinato de um tirano. A partir dos mesmos livros, aqueles que vivem numa monarquia formam a opinião de que os súditos de um Estado popular gozam de liberdade e aqueles que o são de uma monarquia são todos escravos. [...] Em suma, não consigo imaginar coisa mais prejudicial a uma monarquia do que a permissão de se lerem tais livros em público, sem mestres sensatos lhes fazerem aquelas correções capazes de lhes retirar o veneno que contêm: veneno esse que não hesito em comparar à mordida de um cão raivoso, que constitui uma doença denominada pelos físicos hidrofobia, ou medo da água (HOBBES, 2005, p. 191, grifo do autor). 
A doença social da política moderna é, portanto, uma doença de palavras colocadas fora de lugar. $\mathrm{O}$ acontecimento da revolução, emblemático para a escrita contemporânea da História, é identificado pelo autor como escândalo da "conflagração dos discursos e da confusão dos tempos", estabelecendo a relação entre o acontecimento e o anacrônico (RANCIÈRE, 1994, p. 39). Há revolução, porque as pessoas não se identificam com "seu tempo" e com sua ordem social dada pela tradição. A verossimilhança, portanto, perde todo o seu sentido como ordenadora das ações e das falas, seja de príncipes e reis, seja de soldados ou operários. Poderíamos, em contrapartida, afirmar que, em concordância com alguns historiadores de nossa época, a verossimilhança sempre esteve submetida à necessidade, por meio das provas (tekméria), garantindo a atualidade da retórica como base para a pesquisa e a escrita da História. Mas, um desses historiadores de "nosso tempo" afirma, logo adiante, de maneira quase imperceptível, que:

[...] fora dessas conexões necessárias, os historiadores se movem no âmbito do verossímil (eikos), às vezes do extremamente verossímil, nunca do certo mesmo que, nos seus textos, a distinção entre „extremamente verossímile e „,certo" tenda a se desvanecer. [...] De Tucídides até os dias de hoje, os historiadores têm preenchido, tacitamente, as lacunas da documentação com o que é (ou a eles parece) natural, óbvio e, consequentemente, (quase) certo (GINZBURG, 2002, p. 58).

Apesar da insistente afirmação da primazia da prova necessária como principal argumento do historiador contemporâneo, admite-se um amplo espaço para a verossimilhança na escrita da História, como forma de "preencher as lacunas da documentação" com o que lhes parece "natural", "óbvio" e "quase certo". Isso não seria uma forma bastante clara de arrogar ao historiador e seu métier a autoridade sobre o passado para que, ao lado dos que exercem o comando do povo e da gentalha, possa ser dada continuidade à diferença de naturezas entre os reis-filósofos - que possuem a palavra (lógos) - e os escravos, que apenas usam a voz (foné) para a dor e o prazer? Haveria espaço para a palavra "fora de lugar" e revolucionária nessa concepção de História, tão preocupada em identificar e até mesmo caçar todas as impropriedades da palavra fora de contexto, que assombra qualquer forma de ordem presumida e que desfaz as fronteiras entre o "popular" e o "erudito" em uma mesma "época"?

Continuando nossa argumentação a respeito da relação que Rancière operacionaliza entre o programa da Nova História e o da ruptura com os postulados da retórica e poética antigas, temos, em segundo lugar, outro problema relevante: o 
historiador da Nova História não mais se baseará na imitação da fala dos antigos mestres do passado como exemplos pedagógicos de moral e de justiça, mas sim, fará a operação literária de "deslizamento dos tempos" das esferas do relato e do discurso, convergindo em um "presente histórico" que ultrapassa os tempos verbais dos discursos judiciário, epidítico e deliberativo da retórica antiga.

No segundo capítulo de Os nomes da história, Rancière faz alusão aos trabalhos de Émile Benveniste - principalmente, o livro Problemas de linguística geral - para situar a diferença entre os tempos verbais de relato e do discurso. Benveniste entende que a narrativa histórica, ao utilizar formas de terceira pessoa e tempos verbais como o aoristo, imperfeito e mais-que-perfeito (BENVENISTE, 1976, p. 262), faz com que o historiador desapareça como locutor/narrador em sua textualidade. Dessa maneira, a narrativa histórica possui uma característica que se distancia do plano do discurso, pois este último supõe a existência de um locutor e um ouvinte - em que há a intenção de influenciar o outro - e, ao mesmo tempo, permite ao locutor (orador) o emprego de todas as formas pessoais do verbo (eu, tu, ele) e outros tempos verbais como o presente (BENVENISTE, 1976, p. 267-268). Benveniste afirma que este só é utilizado pelos historiadores como um "presente intemporal" ou um "presente de definição" (BENVENISTE, 1976, p. 262-263). Além disso, o linguista francês defende que "o autor permaneça fiel ao seu propósito de historiador" e afaste o que é estranho à narrativa como os discursos, por exemplo. Dessa forma, "os acontecimentos parecem narrar-se a si mesmos", na medida em que o narrador desaparece em sua própria narrativa (BENVENISTE, 1976, p. 266-267).

No entanto, Rancière destaca que, ao contrário da separação realizada por Benveniste, os historiadores da Nova História - a partir da inspiração dada por Jules Michelet ao narrar as Festas da Federação, ocorridas em 1790, no seu livro História da Revolução Francesa - acabaram por deslocar os tempos do relato e do discurso em um único "presente histórico", cujo "tempo da regra é idêntico ao tempo do acontecimento" e, simultaneamente, o próprio e o figurado também são indiscerníveis na narrativa desses historiadores (RANCIÈRE, 1994, p. 23). Como se dá, na prática, essa indiscernibilidade comentada pelo filósofo francês? Vejamos alguns exemplos enumerados pelo próprio autor.

Primeiramente, vamos à parte que Michelet escreve sobre as Festas da Federação, em 1790, em sua História da Revolução Francesa: 
Ela [a França] avança com coragem nesse tenebroso inverno, em direção da primavera desejada que promete a luz nova. Qual luz? Não é mais, como em 1789, o amor vago da liberdade. É um objeto determinado, de uma forma fixa, imutável, que conduz toda a nação, que transporta, arrebata os corações; a cada passo que se dá, ele surge ais deslumbrante, e a marcha é mais rápida... Enfim, a sombra desaparece, o nevoeiro se desfaz, a França vê distintamente o que amava, perseguia sem bem apreendê-lo ainda: a unidade da pátria. [...]As próprias Federações, em maior parte, contaram sua história. Elas a escreviam à sua mãe, a Assembleia Nacional, fielmente, ingenuamente, em uma forma com muita frequência grosseira, infantil; diziam como podiam; quem sabia escrever, escrevia. Nem sempre se encontrava nos campos escriba hábil que fosse digno de consignar essas coisas na memória. A boa vontade a isso supria... Veneráveis monumentos da fraternidade nascente, autos informes, mas espontâneos, inspirados na França, permanecereis para sempre para dar testemunhos do coração de nossos pais, de seus arroubos, quando pela primeira vez viram a face três vezes amada da pátria [...] Redescobri isso tudo inteiro, ardente, como se houvesse ocorrido ontem, ao fim de sessenta anos, quando recentemente abri esses papéis, que pouca gente lera. À primeira abertura, fui tomado de respeito; senti uma coisa singular única, em que não se pode enganar-se. Esses relatos entusiastas dirigidos à pátria (representada pela Assembleia) são cartas de amor. Nada de oficial nem de encomendado. Visivelmente, o coração fala. O que aí se pode encontrar de arte, de retórica, de declamação, é justamente a ausência de arte, é o embaraço do homem moço que não sabe como exprimir os sentimentos mais sinceros, que emprega as palavras dos romances, na falta de outras, para dizer um amor verdadeiro. Mas, a cada momento, uma palavra arrancada do coração protesta contra essa impotência de linguagem, fazendo avaliar a profundeza real do sentimento... (MICHELET, 1989, p. 400-403).

Vemos, nesse belo trecho de Michelet, uma escrita que põe em um mesmo quadro narrativo uma série de elementos simultâneos: 1) a narração do momento descrito; 2) o surgimento da nação-França como uma personagem da história em conjunto com seus agentes; 3) os "monumentos da fraternidade nascente" como testemunhos vivos desse momento histórico no presente; 4) o sentimento do próprio historiador ao encontrar os documentos pouco lidos nos arquivos após sessenta anos de quase total esquecimento. Para que todos esses elementos estejam presentes em um mesmo tempo, Michelet teve que empregar o que Rancière chama de "princípio poético de indiscernibilidade", ligado à poética romântica do século XIX, em que os antigos cânones da retórica e da poética, baseados na verossimilhança, são substituídos pela copresença de várias temporalidades em um só presente histórico, combinando os tempos do relato e do discurso. O próprio autor, mais adiante em seu livro, aponta um detalhe importante acerca dessa forma de confundir os tempos:

A ciência histórica não se ganha contra as tentações da narrativa e da literatura, ela se ganha pelo encadeamento da mímesis no relato. Ela não se ganha apenas os exageros do romantismo, ela se ganha no próprio seio deste movimento chamado romantismo que significa primeiro o fim do reino mimético e a transformação das regras da Letras no incondicionado da literatura (RANCIÈRE, 1994, p. 60). 
É nesse momento que o filósofo francês faz referência a elementos importantes da poética romântica oitocentista. No livro, L'Absolu littéraire ( $O$ absoluto literário em português), de Jean-Luc Nancy e Philippe Lacoue-Labarthe, publicado, na França, em 1978, os autores destacam a relevância do fragmento como fundamento de toda a criação poética do romantismo. Compreendido em seu "inacabamento essencial", o fragmento é sempre um projeto que não funciona como programa ou prospectiva, mas sim, como projeção imediata do que, no entanto, não acaba. Em outros termos, o fragmento funciona, simultaneamente, como "resto de individualidade" e como “individualidade" (NANCY; LACOUE-LABARTHE, 2012, p. 86-87). A noção romântica do fragmento engloba, portanto, uma totalidade que não pode estar situada em nenhum ponto: "encontra-se simultaneamente no todo e em cada parte" (NANCY; LACOUE-LABARTHE, 2012, p. 88). Ainda no livro, os autores apontam que o fragmento rompe com a ideia de mímesis em, pelo menos, dois aspectos principais: em primeiro lugar, o de que, conforme Friedrich Schlegel, a humanidade não pode ser ensinada, não pode ser "inoculada" (NANCY; LACOUE-LABARTHE, 2012, p. 285). Em segundo lugar, segundo August Schlegel, a função de exemplaridade, própria da noção pedagógica da mímesis, perde o seu significado na medida em que ela é substituída pela ideia de se "apropriar das máximas de seu atuar" (NANCY; LACOUELABARTHE, 2012, p. 428). Nesse sentido, os escritores de L'Absolu littéraire defendem que os românticos convertem o sentido atribuído antes de imitação para o de criação artística, sem mais haver a mediação própria da mímesis (NANCY; LACOUELABARTHE, 2012, p. 239-241). Cada um, em última instância, cria a si mesmo sem a mediação do condutor, do rei-filósofo dono da palavra e do discurso persuasivo.

É, portanto, na valorização do fragmento como elemento principal da criação artística romântica que se pode estabelecer a ponte entre a escrita de Michelet e a ruptura com a antiga mímesis retórico-poética. Todos os tempos estão juntos, convergindo em fragmentos de impressões que, juntos, montam uma grande narrativa em que cada coisa tem seu significado autônomo. Não há, portanto, um fio condutor dado pela ação principal (mimética) - mediada pela intenção autoral -, dando abertura a outro princípio pedagógico para a humanidade.

Entramos, agora, no terceiro momento de nossa demonstração de como a Nova História rompe com os critérios da retórica e poética antigas: o da narrativa dos "testemunhos mudos", em discurso indireto, em substituição às ações políticas dos reis 
e príncipes como saída encontrada para introduzir a vida das "massas anônimas" como sujeitos da história.

Este movimento literário de narração dos “testemunhos mudos" já está presente na narrativa histórica de Michelet, quando descreve os testemunhos vivos das Festas da Federação, nos quais os agentes - que escreveram cartas de amor à pátria-mãe de maneira "grosseira", "infantil" - tornaram-se, aos olhos do historiador que leu os documentos quase intocados dos arquivos, "veneráveis monumentos da fraternidade nascente, autos informes, mas espontâneos, inspirados na França", em que "o coração fala". O historiador vê, nesses monumentos, pura "ausência de arte", "impotência da linguagem, fazendo avaliar a profundeza real do sentimento" (MICHELET, 1989, p. 402-403). Nota-se, aí, um movimento interessante por parte do historiador oitocentista que inspirou a Escola dos Annales, surgida há mais de oitenta anos: ao considerar a "entrada dos anônimos do povo no universo de seres falantes", o relato se organiza de outro modo. É o "historiador que vai colocar-se em cena, mostrar-se a nós tendo às mãos estes relatos das federações que são, diz-nos ele, bem mais que relatos, cartas de amor à pátria nascente" (RANCIÈRE, 1994, p. 52-53).

Ora, essa questão está, conforme Rancière, estreitamente vinculada ao problema da verdade em relação à arte mimética. Platão, em um trecho do terceiro livro de $A$ República (392 c - 394 b), aponta o problema relativo ao fato do poeta se ocultar em seus versos e narrativas com o uso de imitações (mímesis). Sócrates, em tom de desaprovação ao poeta que se "oculta" em meio às imitações - porque não se pode extrair dele sua intenção como indivíduo - realiza outra forma de narrar uma passagem do início da Ilíada de Homero, sem imitar (mímesis) os diálogos que estão na cena, mas faz apenas uma narração (diégesis) dos fatos ocorridos (PLATÃO, 2006, p. 97-99). O filósofo francês complementa que

[e]sta condenação da mímesis trágica caminha junto em Platão com a de democracia. A ilusão trágica pertence ela própria ao reino democrático da aparência e da lisonja, reino em que o arbitrário do orador e o do demos refletiam-se um ao outro interminavelmente. [...] Utilizando seus poderes antimiméticos, o relato não seria próprio para dar à poesia uma regime de verdade? E por que não à democracia? Ora é justamente $\mathrm{m}$ tal uso que Michelet inventa, o democrata cuidadoso em converter a democracia em verdade, em subtraí-la aos prestígios da retórica e às violências da tragédia. Ele usa os poderes do relato para destruir o sistema da mímesis [...] (RANCIÈRE, 1994, p. 59, grifos nossos). 
Dessa maneira, Rancière aponta, na escrita micheletiana, um relato das Festas da Federação que, em seu poder de narrar os fatos associados sem imitação das falas dos personagens do povo - tal como o Sócrates havia prescrito de Platão -, coloca o historiador no centro do relato, como aquele que leu os documentos/monumentos populares e, ao "dar a voz" ao povo, rouba-lhe novamente a fala. Nesse caso, como bem assevera o autor de Os nomes da história, "a voz do povo não é mais a dos oradores" (RANCIÈRE, 1994, p. 59).

Falar em nome do povo, usando "testemunhos mudos" para lhes relatar sua verdade, pertence, por sua vez, ao mesmo regime de verdade da literatura que põe em pé de igualdade o que é inimitável como a marca do verdadeiro. Vejamos, ainda em Michelet, um trecho de seu livro, Origines du droit français, de 1837, em que trata da prática antiga de exposição das crianças e sua reprovação diante dessa crueldade:

\footnotetext{
Na Antiguidade clássica ou bárbara, a criança colocada aos pés do pai não tem direito à vida até o pai a ter levantado, desde que não tenha gostado dos elementos sob a forma de leite ou de mel. $\mathrm{O}$ uso de crianças expostas foi universal, especialmente em nossos climas tristes. [...] Escória do homem, livre na natureza, ele era frequentemente acolhido por ela. Ela o adotava, a rude mãe, lhe cobria de folhas seu frio leito, ela o ninava com o vento do Norte, o alimentava com o leite das lobas, com a medula dos leões. [...] Quais eram as queixas das mães? Só elas poderiam dizê-lo. As pedras as chorariam. O próprio oceano emudece ouvindo a Dânae de Simônides (MICHELET, 1837, p. 10-11).
}

Ao relatar a exposição das crianças e sua adoção pela "rude mãe" que o acolhia, Michelet afirma que só as mães poderiam dizer suas queixas em forma de uma contra preterição retórica. Como destaca Rancière, "ela é o inverso exato do que é a preterição na tradição retórica: uma mímesis inconfessável. A preterição representa por fraude o que não convém representar" (RANCIÈRE, 1994, p. 62). Assim, a impossibilidade de imitação da queixa das mães no relato de Michelet produz o "testemunho mudo que detém a verdade da ciência, que a detém sem poder libertá-la de si mesma [...] instância legitimadora do saber" (RANCIÈRE, 1994, p. 63).

Curiosamente, a escrita dos testemunhos mudos é a mesma que se encontra em um novo conceito de poesia e da palavra poética. Ela se confunde, simultaneamente, com a busca que Vico empreende do "verdadeiro Homero" e do programa da poética romântica, em que tudo fala igualmente, sem que as ações da trama tenham primazia sobre os micro eventos, os detalhes da escrita que igualam as impressões singulares e os elementos universais. 
Os testemunhos mudos são, inicialmente, a afirmação viconiana de que Homero foi "o organizador da política, ou seja, da civilização grega" (VICO, 2005, p. 651), devido ao fato de ter descrito, em suas obras poéticas, os usos e costumes das gentes da Grécia. Tal descrição nua dos costumes gregos antigos foram considerados por Aristóteles como "insuperáveis as mentiras homéricas" e que, por sua vez, Horácio teria considerado "inimitáveis os seus caracteres" (VICO, 2005, p. 626). Por se tratar de uma descrição da humanidade em sua infância, Vico defende a tese de que "torna-se impossível terem sido inventados com tanta naturalidade e felicidade por um filósofo" (VICO, 2005, p. 627). Desse modo, o inimitável deixa de ser pensado como mentira, mas sim, como testemunho verdadeiro de uma época longínqua, em que a humanidade se comportava de maneira bárbara e rude. Conforme Rancière em, La parole muette ( $A$ palavra muda em português), Vico "mudou o estatuto da poesia": em vez de ser uma "atividade que produz os poemas", torna-se a "qualidade dos objetos poéticos". "A poesia se define pela poeticidade [...] A poesia é a manifestação de uma poeticidade que pertence à essência primeira da linguagem - 'poema do gênero humano em seu conjunto e dirá August Schlegel” (RANCIÈRE, 2009, p. 55).

Também são os testemunhos mudos uma forma de literatura que, em seu relato realista da vida das personagens, coloca o insignificante ao lado do significante em igualdade de posições. É, por exemplo, a passagem de Madame Bovary, de Gustave Flaubert, em que Emma e Rodolphe teriam se tocado em um ambiente de campo nos primeiros dias de outubro:

\footnotetext{
Samambaias compridas que bordejavam o caminho agarravam-se ao estribo de Emma. Rodolphe, enquanto avançava, inclinava-se para retirá-las à medida que iam se prendendo. Outras vezes, para afastar os galhos, ele passava perto dela, e Emma sentia seu joelho roçar em suas pernas. O céu estava azul. As folhas não se mexiam. Havia grandes espaços repletos de urzes floridas; camadas de violetas alternavam-se com a mistura de árvores cinzentas, avermelhadas ou douradas, de acordo com a diversidade das folhagens (FLAUBERT, 2011, p. 157)
}

O romance entre Emma Bovary e Rodolphe acontece ao mesmo tempo em que o céu, as folhas e as árvores dos campos de outubro são testemunhos mudos da vida das personagens. Como nos diz Rancière, tudo está gravado "na textura das coisas": "ela se lê melhor lá onde ninguém procura falar, ninguém procura enganar":

A teoria do testemunho mudo ata dois enunciados à primeira vista contraditórios. Primeiramente, tudo fala, não há mutismo, nenhuma fala perdida. Em segundo lugar, só fala verdadeiramente o que está mudo (RANCIÈRE, 1994, p. 65). 
Podemos afirmar, portanto, que a história acadêmica, cuja inspiração foi dada por Michelet, só consegue se tornar uma escrita dos anônimos que "fazem história" na mesma medida em que se emancipa da fala dos oradores e dos reis para se inscrever na superfície das coisas, no cotidiano do povo em sua marcha. Entretanto, o historiador, ao "dar voz ao povo", o faz calar, substituindo o discurso direto pelo discurso indireto, sem imitação, em um relato que põe o historiador erudito na linha de frente para dizer o que leu em seus arquivos dos documentos/monumentos da cultura popular.

\title{
Do rei morto à heresia: Braudel, a História social-cultural das últimas décadas e o regime de verdade da Nova História
}

A morte do rei é o traço inaugurador da Nova História. Fernand Braudel, ao final de seu livro, O Mediterrâneo e o mundo mediterrânico na época de Filipe II, atesta um fato que desconcerta a narrativa até então realizada: o da morte de Filipe II:

\begin{abstract}
Na exposição dos acontecimentos do palco mediterrânico, não citamos, na devida altura, um acontecimento sensacional, que correu o mar e o mundo: a morte de Filipe II, verificada a 13 de setembro de 1598, no Escorial, no declínio de um longo reinado que tinha parecido interminável aos seus adversários. Omissão? Mas significou o desaparecimento do Rei Prudente uma grande mudança na política espanhola? [...] Agentes espanhóis continuarão as suas intrigas em Constantinopla, para aí negociarem uma paz impossível e empenharem-se eficazmente em evitar os seus embates [...]Tudo é continuidade, mesmo, apesar da sua morosidade, o regresso à paz que se impõe depois dos esforços desordenados, mas poderosos dos últimos anos do reinado de Filipe II (BRAUDEL, 1995, vol. 2, p. 616-617).
\end{abstract}

Acerca dessa afirmação aparentemente colocada ao acaso por Braudel, Rancière sustenta que "ele vai contar este acontecimento que é um não-acontecimento, fora da localidade e lugar que lhe devia caber"; deslocando o acontecimento para o fim do livro, Braudel transforma-o "em sua própria metáfora": "A morte do rei significa que os reis estão mortos como centros e forças da história” (RANCIÈRE, 1994, p. 19-20).

A morte do rei, assim como a vacância do poder e o acontecimento revolucionário, são eventos que cortam a lógica de estruturação das interpretações históricas baseadas nos "velhos métodos", exigindo uma nova postura por parte do historiador. Braudel escolhe, portanto, um novo sujeito para sua escrita histórica a fim de substituir o rei morto: o mar. 
Não é um homem com grandes ideias: [...] Não existe nenhuma das suas notas que não seja um pequeno fato preciso, uma ordem, uma observação, até mesmo a correção de um erro de ortografia ou de geografia. [...] Não creio que a palavra Mediterrâneo tenha alguma vez flutuado no seu espírito com o conteúdo que nós lhe atribuímos. [...] Uma verdadeira geografia não fazia parte da educação dos príncipes. São razões suficientes para que esta longa agonia, terminada em setembro de 1598, não seja um grande acontecimento da história mediterrânica. Para que se assinalem de novo as distâncias da história biográfica à história das estruturas e, mais ainda, às dos espaços... (BRAUDEL, 1995, p. 617-618).

Deslocar a história dos reis para o mar é uma das formas que Braudel, seguindo o rastro da escrita de Michelet, é resultado do deslizamento dos tempos do relato e do discurso que tratamos anteriormente. Ao falar da montanha, por exemplo, Braudel coloca na mesma narrativa diversos tempos diferentes em coexistência, demonstrando a indiscernibilidade poética entre o que é real e o que é simbólico:

O montanhês é uma figura humana bem popular em toda a literatura mediterrânica. Conta Homero que os Cretenses desconfiam dos selvagens das suas montanhas, e Telêmaco, regressado a Ítaca, avoca o Peloponeso coberto de flores, onde viveu entre sujos aldeões, ,comedores de bolotas ${ }^{\text {ee }}$. [...] O que é, ao certo, uma montanha? Pouco ajuda para a definição um conceito simples como, por exemplo, o conjunto das terras mediterrânicas de altitude superior a quinhentos metros, até porque se trata de escalas humanas de valor, escalas incertas, difíceis de referenciar nos mapas. De resto, já há muito Raoul Blanchard lançara o aviso: „Uma definição de montanha que seja clara e compreensível é, em si mesma, quase impossível de formulare [...] Normalmente, a montanha é um mundo que vive à margem das civilizações, produto das cidades e das regiões baixas. A história da montanha é não ter história, é ficar, habitualmente, fora das grandes correntes civilizadoras, mesmo que estas evoluam com lentidão. Mesmo Roma não teria tido uma grande influência nestes mundos alcantilados, apesar do seu espantoso tempo de vida [...] (BRAUDEL, 1995, vol. 1, p. 40-44).

A escrita de Braudel, ao tratar dos "testemunhos mudos da história" - como as montanhas, as planícies, as ilhas, juntamente com os "destinos coletivos" e os "movimentos de conjunto" da economia movida pelos anônimos -, realiza o mesmo trabalho inaugurado por Michelet ao tratar da Revolução Francesa e das Festas da Federação: coloca-os todos em sua anacrônica simultaneidade, da mesma forma em que rompe com as regras da retórica e da poética antigas, destruindo o sistema da mímesis, construída com base na necessidade e na verossimilhança. Em meio a tais exemplos de escrita histórica, Rancière aponta a semelhança entre a morte do rei e a "teoria do testemunho mudo" em um importante aspecto: ambas são a construção de uma "teoria do lugar de fala". 
A inclusão da morte e a teoria do testemunho mudo são uma só e mesma teoria: uma teoria do lugar de fala. É nesta definição de um lugar da fala que se ata um pensamento do túmulo e um pensamento do solo; uma teoria da morte como passagem das vozes e uma teoria do espaço como inscrição do sentido. Sem esta articulação, compreender-se-ia mal a dupla preocupação que não cessa de guiar as direções de pesquisa da nova história em direção aos territórios aparentemente distantes da geografia e da religião (RANCIÈRE, 1994, p. 73).

A "geografização do sentido", termo empregado por Rancière para abarcar esse movimento de escrita da história que vai de Michelet a Braudel, ocupa um lugar importante na teoria do lugar de fala da Nova História, o de "dar lugar às diversas vozes" para colocá-las cada uma em seu "devido lugar", sem perturbar as ordenações conceituais e sociológicas dadas a priori para ler um determinado "contexto histórico":

\begin{abstract}
A „base ee geográfica que Michelet dá à história, mesmo se ela é uma resposta à teoria das raças, não é a submissão dos fatos históricos aos dados geográficos. É, bem mais profundamente, uma geografização ou uma territorialização do sentido. Não se trata da influência do solo ou do meio. [...] A ,geografia ${ }^{e e}$ que chama a nova história é primeiro um espaço simbólico que dá aos reis uma boa morte e funda a condição primeira da ciência histórica: nenhuma fala permanece sem lugar. [...] Esta distribui o excesso das palavras e a partilha das vozes entre terra e mar, entre planícies e montanhas, ilhas e penínsulas. [...] A teoria micheletiana do lugar descarta a possibilidade de que nenhuma fala seja vã. Ela interdiz o não-sentido fazendo de toda produção de fala a expressão exata de sua causa. [...] Digamo-lo de outro modo: não há heresia possível. E pode-se compreender aqui a necessidade que liga o pensamento territorial da nova história à questão da dissidência religiosa (RANCIÈRE, 1994, p. 74, grifo nosso).
\end{abstract}

Tal raciocínio está ligado, curiosamente, ao movimento de "caçar a heresia" onde ela estiver - e, por meio de um verdadeiro paradigma indiciário, colocá-la em seu "lugar social" entre as classes e suas disputas, entre as instâncias do "erudito" e do “popular”, como se tais conceitos não fossem já colocados de princípio para ordenar a narrativa que põe a fala excessiva ou perturbadora em uma tranquila classificação social. ${ }^{4}$ Esse esquema tripartite, que situa o "tempo dos vencidos" em evidência, lembra bem Rancière, segue de maneira constante a "teleologia espontânea da modernidade", que posiciona o mais atrasado como preparação para o mais avançado:

[...] bem em baixo, o mundo da repetição, o das "soluções vindas da noite dos tempos", do fechamento estreito do círculo de possibilidades quase imutáveis; o tempo dos vencidos, dos "homens pouco lúcidos", "materialmente e intelectualmente incapazes de se lançarem para transpor estes limites estreitos do possível". Acima, o tempo "vivo e tagarela" das mudanças sobre o qual vai construir-se um terceiro tempo, o tempo dos

\footnotetext{
${ }^{4}$ Para maiores detalhes, ver os seguintes livros da História social/cultural das últimas décadas que inspiraram e ainda inspiram vários estudos atuais na área da História: FEBVRE, 2009; GINZBURG, 2006; LE ROY LADURIE, 1997.
} 
vencedores do capitalismo gerador de um mercado e de uma história em escala mundial. Este movimento do mais atrasado para o mais avançado, do mais lento para o mais vivo, do mais simples e do mais obtuso para o mais complexo e o mais racionalmente organizado está de acordo com a teleologia espontânea da modernidade (RANCIÈRE, 1994, p. 87).

Esse mesmo esquema, que considera "a anatomia do homem como chave para a anatomia do macaco" - raciocínio exposto na Introdução da Contribuição à Crítica da Economia Política de Karl Marx (MARX, 2008, p. 264) para afirmar que é por meio da economia burguesa que se torna possível conhecer a economia da Antiguidade e assim por diante - permite, também, o esquema inverso que avalia "o mais primitivo" como princípio de explicação ou matriz de sentido do "mais avançado". A ordem narrativa do Mediterrâneo de Braudel é, por sua vez, dependente desse segundo esquema, que não revoga a "teleologia espontânea da modernidade", mas a mantém em conjunto com a "racionalidade sedutora do economista rei e do sociólogo erudito" (RANCIÈRE, 1994, p. 87).

A partir da demonstração desse raciocínio, que está na base da "revolução" da Nova História, torna-se possível, neste momento, compreender um mecanismo teóricometodológico ainda amplamente usado nas interpretações históricas em nosso meio acadêmico: o que põe as massas anônimas em evidência para as colocar, de antemão, como "chave heurística" que antecipa e dá sentido aos "vencedores", colocando a fala excessiva e revolucionária em seu encolhido "lugar de fala".

Novamente, Rancière é um autor importante para que se possa, na área acadêmica da História, repensar o papel do historiador e o uso de conceitos e noções para dar base à sua narrativa. A “operação historiográfica”, tão cara aos defensores dos métodos na Nova História, encontra-se em uma situação contraditória. Ela pretende, ao mesmo tempo, dar evidência aos anônimos e pôr o historiador erudito como aquele que "representa" a fala do considerado "mais primitivo"; ela só consegue dar sentido à vida das massas se contrariar e implodir todo o antigo sistema retórico-poético da historiografia antiga que colocava as falas em seu lugar pressuposto de autoridade para dar sentido à narrativa; ela implode o sistema mimético e também adota procedimentos próximos aos da literatura romântica - o que, em tese, contradiz as aferradas teses da separação clara entre "História" e "Literatura"; ela se realiza, em última instância, na medida em que o "real" e o "simbólico" se põem no mesmo regime de verdade: 
O que determina a vida dos seres falantes, tanto quanto e mais que o peso do trabalho e de sua remuneração é o peso dos nomes ou de sua ausência, o peso das palavras ditas e escritas, lidas e ouvidas, um peso tão material quanto qualquer outro. A questão não concerne, pois, à boa ordem das causas. Ela concerne ao regime de verdade que liga o discurso histórico a seu objeto (RANCIÈRE, 1994, p. 102, grifos nossos).

Qual é, enfim, o regime de verdade da Nova História e da História social/cultural das últimas décadas? Ora, é aquele que se encontra em meio à historicidade democrática:

O problema de nossa ciência histórica é primeiro o de sua relação necessária e infeliz com "sua" historicidade, a historicidade democrática: a dispersão dos atributos da soberania e das lógicas da subordinação, a diferença indefinida do homem e do cidadão, a possibilidade para qualquer ser falante ou qualquer coleção aleatória de falantes ser, não importa como, sujeitos da história (RANCIÈRE, 1994, p. 105).

Infelizmente, não há uma saída fácil para esse problema. O próprio regime de verdade em que se encontra a História com atributos de ciência é o mesmo que põe as palavras da História em conjunto e em descontinuidade com os eventos, quebrando a antiga hierarquia que separava, por natureza, os reis-filósofos da arraia-miúda. O regime estético da arte, no interior do qual os românticos viram no fragmento a totalidade da experiência estética, é o mesmo que aponta para outra noção de sentido comunitário diferente do sensus communis da tradição retórica -, em que se reconhece a capacidade que qualquer um possui para estabelecer seus juízos diante de todos com autonomia, sem revogar das regras do viver em comum (heteronomia). Aqui, é relevante apontar que a inspiração kantiana no pensamento de Rancière é uma chave fundamental para a compreensão de seus resultados de pesquisa sobre a História entre outros autores por ele mobilizados. $^{5}$

Em último lugar, é importante fazer a já antiga ressalva: em vez de "destruir" a autoridade da História, assumir a historicidade democrática da Nova História - no interior do regime estético da arte - apenas pode, com boa vontade, fazer com que, realmente, o historiador se ocupe com as falas excessivas e revolucionárias sem que as coloque, novamente, em um esquema teleológico que defenda uma certa ordem determinada a priori. Cabe a nós, portanto, fazer a escolha. O caminho sempre esteve aberto: nós é que, talvez, continuemos perdidos em meio às sombras de certos fantasmas da historiografia.

\footnotetext{
${ }^{5}$ Sobre o assunto, ver os livros: RANCIÈRE, 2005, 2012; KANT, 2008.
} 


\section{REFERÊNCIAS}

AUERBACH, Erich. Mímesis. São Paulo: Perspectiva, 2004.

BENVÉNISTE, Émile. As relações de tempo no verbo francês. In: BENVÉNISTE, Émile. Problemas de linguística geral. São Paulo: Ed. Nacional; EDUSP, 1976. p. 260276.

BRAUDEL, Fernand. O Mediterrâneo e o mundo mediterrânico na época de Filipe II. Lisboa: Dom Quixote, 1995. 2 vols.

CICÉRON. De l'invention. Paris: Les Belles Lettres, 2002.

FEBVRE, Lucien. O problema da incredulidade no século XVI: a religião de Rabelais. São Paulo: Companhia das Letras, 2009.

FLAUBERT, Gustave. Madame Bovary. Porto Alegre: L\&PM, 2011.

GADAMER, Hans-Georg. Verdade e Método I. Petrópolis: Vozes, 2008.

GINZBURG, Carlo. O queijo e os vermes. São Paulo: Companhia das Letras, 2006.

GINZBURG, Carlo. Relações de força. São Paulo: Companhia das Letras, 2002.

KANT, Immanuel. Crítica da Faculdade do Juízo. Rio de Janeiro: Forense Universitária, 2008.

LE ROY LADURIE, Emmanuel. Montaillou, povoado occitânico de 1294 a 1324. São Paulo: Companhia das Letras, 1997.

MARX, Karl. Contribuição à Crítica da Economia Política. São Paulo: Expressão Popular, 2008.

MICHELET, Jules. História da Revolução Francesa. São Paulo: Companhia das Letras, 1989.

MICHELET, Jules. Origines du droit français. Paris: L. Hachette, 1837. Disponível em: <http://gallica.bnf.fr/ark:/12148/bpt6k97586896>. Acesso em: 18 out. 2017.

MONTAG, Warren. Introduction to Althusseres "Student Problems". Radical Philosophy, Charlottesville, VA (EUA), n. 170, p. 8 - 15, nov./dez. 2011.

NANCY, Jean-Luc; LACOUE-LABARTHE, Philippe. EI absoluto literario. Teoría de la literature del romanticismo alemán. Buenos Aires: Eterna Cadencia, 2012.

RANCIÈRE, Jacques. A noite dos proletários. São Paulo: Companhia das Letras, 1988.

RANCIÈRE, Jacques. A partilha do sensível. São Paulo: Editora 34, 2005.

RANCIÈRE, Jacques. Althusser's Lesson, trad. Emiliano Battista. Londres/Nova 
Iorque: Continuum, 2011.

RANCIÈRE, Jacques. L“excès des mots: pratiques de desidentification et logiques heterogènes de la culture. Entretien avec Jacques Rancière. Por Maria-Benedita Basto e José Neves, Práticas da História, Journal on Theory, Historiography and Uses of the Past, Lisboa, vol. 1, no 1, p. 185-214, 2015. Disponível em:

<http://www.praticasdahistoria.pt/issues/2015/11/PDH_01_JacquesRanciere.pdf>.

Acesso em: 13 out. 2017.

RANCIÈRE, Jacques. La méthode de l'égalité. Montrouge: Bayard, 2012.

RANCIÈRE, Jacques. La palabra muda. Ensayo sobre las contradicciones de la literatura. Buenos Aires: Eterna Cadencia, 2009.

RANCIÈRE, Jacques (Org.). Louis Gabriel Gauny: le philosophe plébéien. Paris/Saint-Denis: La découverte-Maspero; PUV, 1983.

RANCIÈRE, Jacques. O conceito de crítica e a Crítica da Economia Política dos Manuscritos de 1844 a O Capital. In: ALTHUSSER, Louis; RANCIÈRE, Jacques; MACHEREY, Pierre (Org.). Ler o Capital. vol. I. Rio de Janeiro: Zahar, 1979. p. 75172.

TÁCITO. Anais. Trad. De J. L. Freire de Carvalho. Rio de Janeiro: W. M, Jackson, 1950.

VICO, Giambattista. Ciência Nova. Lisboa: Calouste Gulbenkian, 2005.

VICO, Giambattista. On the study methods of our time [De nostri temporis studiorum ratione]. Trad. de Elio Gianturco. Ithaca (NY, EUA): Cornell University Press, 1990. 